7. Paul K., Krajča V., Roth Z., Melichar J., Petránek S. Comparison of quantitative EEG characteristics of quiet and active sleep in newborns. Sleep Medicine. 2003;4(6):543-552. doi: 10.1016/j.sleep.2003.08.008

8. Janjarasjitt S., Scher M. S., Loparo K. Nonlinear dynamical analysis of the neonatal EEG time series: The relationship between neurodevelopment and complexity. relationship between neurodevelopment and complexity.
Clinical Neurophysiology. 2008;119(8):822-836. doi: 10.1016/j.clinph.2007.11.012

9. Löfhede J., Thordstein M., Löfgren N., Flisberg A., RosaZurera M. [et al.] Automatic classification of background EEG activity in healthy and sick neonates. Journal of Neural Engineering. 2010;7(1). doi: 10.1088/17412560/7/1/016007

10. Krajča V. Petránek S., Mohylová J., Paul K., Gerla V. [et al.] Modeling the microstructure of neonatal EEG sleep stages by temporal profiles. Proc. IFMBE Proceedings of the 13th International Conference on Biomedical Engineering (CBME2008). 2009;23:133-137.

11. Scher M. S. Steppe D. A., Banks D. L., Guthrie R. D., Sclabassi R. J. Maturational trends of EEG-sleep measures in the healthy preterm neonate. Pediatr. Neurol. 1995;12(4):314-22. doi: 10.1016/08878994(95)00052-H

12. O'Toole J. M., Boylan G. B., Vanhatalo S., Stevenson N. J. Estimating functional brain maturity in very and extremely preterm neonates using automated analysis of the electroencephalogram. Clinical Neurophysiology. 2016:127(8):2910-2918. doi: 10.1016/j.clinph. 2016.02.024

13. Chipman H., George E., McCullock R. Bayesian CART model search. Journal of American Statistics. 1998;93(443):935-960. doi: 10.1080/01621459.1998. 10473750

14. Denison D. G. T., Holmes C. C., Mallick B. K., Smith A. F. M. Bayesian Methods for Nonlinear Classification and Regression. Wiley, 2012.

15. Schetinin V Jakaite L. Classification of newborn EEG maturity with Bayesian averaging over decision trees. Expert Systems with Applications. 2012;39(10):93409347. doi: 10.1016/j.eswa.2012.02.184

16. Nolan H., Whelan R., and Reilly R. B. FASTER: Fully Automated Statistical Thresholding for EEG artifact Rejection. J. Neurosci Methods. 2010;192(1):152-62. doi: 10.1016/j.jneumeth.2010.07.015

17. Schetinin V., Jakaite L. Extraction of features from sleep EEG for Bayesian assessment of brain development. PLOS ONE. 2017;12(3):e0174027. doi: 10.1371/journal. pone.0174027

18. Koolen N., Dereymaeker A., O. Räsänen, Jansen K., Vervisch J. [et al.] Early development of synchrony in cortical activations in the human. Neuroscience. 2016;322:298-307. doi: 10.1016/j. neuroscience.2016.02.017

About authors:

Schetinin Vitaly, PhD, Senior Lecturer; tel.: +441582743120; e-mail: vitaly.schetinin@beds.ac.uk

Jakaite Livija, PhD, Research Assistant; tel.: +441582743120; e-mail: livija.jakaite@gmail.com

(C) Group of authors, 2017

UDC 616-053.2:615.015.81

DOI - https://doi.org/10.14300/mnnc.2017.12084

ISSN - 2073-8137

\title{
CHANGES IN CALCIFEDIOL CONCENTRATIONS IN INFANTS DEPENDING ON THE CHOLECALCIFEROL DOSE AND DURATION OF THERAPY
}

Klimov L. Ya. ${ }^{1}$, Zakharova I. N. ${ }^{2}$, Maltsev S. V. ${ }^{3}$, Malyavskaya S. I. ${ }^{4}$, Yagupova A. V. ${ }^{\text {, }}$ Dolbnya S. V. 1 , Kasyanova A. N. ${ }^{2}$, Kuryaninova V. A. ${ }^{1}$, Bobryshev D. V. 1 , Ivanova A. V. ', Alkhimidi A. A. 1, Temirkhanova I. V.

${ }^{1}$ Stavropol State Medical University, Russian Federation

2 Russian Medical Academy of Continuous Postgraduate Education, Moscow, Russian Federation

3 Kazan Medical Academy of Postgraduate Education, Russian Federation

${ }^{4}$ Northern State Medical University, Arkhangelsk, Russian Federation

\section{АИНАМИКА КААЬЦИАИОАА У АЕТЕЙ ГРУАНОГО ВОЗРАСТА В ЗАВИСИМОСТИ ОТ АОЗЫ И ААИТЕАЬНОСТИ ПРИЁМА ПРЕПАРАТОВ ХОАЕКААЬЦИФЕРОАА}

\author{
А. Я. КАимов ${ }^{1}$, И. Н. Захарова ${ }^{2}$, С. В. Мальцев ${ }^{3}$, С. И. Малявская ${ }^{4}$, А. В. Ягупова ${ }^{1}$, \\ С. В. Аолбня ${ }^{\prime}$, А. Н. Касьянова ${ }^{2}$, В. А. Курьянинова ${ }^{1}$, А. В. Бобрышев ${ }^{1}$, \\ А. В. Иванова ${ }^{1}$, А. А. ААьхимияи ${ }^{1}$, И. В. Темирханова ${ }^{1}$ \\ 1 Ставропольский госуАарственный МеАицинский университет, Российская ФеАерация \\ 2 РосСийская МеАицинская акаАемия непрерывного послеАипломного образования, \\ Москва, Российская ФеАерация \\ ${ }^{3}$ Казанская МеАицинская акаАемия послеАипломного образования, \\ Российская ФеАерация \\ 4 Северный госуАарственный меАицинский университет, Архангельск, \\ Российская ФеАерация
}

The paper presents an analysis of the relationship between the duration of cholecalciferol supplementation at different doses and the 25(OH)D concentration in infants during their first year of life. We evaluated 496 infants aged 1 month to 12 months who were divided into four groups depending on the duration of vitamin $D$ supplementation: up to 8 weeks, $8-15$ weeks, 16-24 weeks, and over 24 weeks. 
The results obtained in this study demonstrate rather low vitamin D levels in infants, both breastfed and formula-fed. It was demonstrated that use of higher (1000-1500 IU/day) prophylactic doses of vitamin $D$ than the conventionally used $500 \mathrm{IU} /$ day dose is justified if the aim is to maintain an optimal serum calcifediol concentration $(30 \mathrm{ng} / \mathrm{mL}$ or higher) in infants in their first year of life, and that the optimal duration of a supplementation course is not less than 16 weeks.

Keywords: cholecalciferol, vitamin D insufficiency, infants, first year of life, prevention, duration of supplementation, feeding

Представлен анализ взаимосвязи между длительностью приёма различных доз препаратов холекальциферола и уровнем 25(OH)D у детей на протяжении первого года жизни. Обследованы 496 детей в возрасте от 1 до 12 месяцев, которые в зависимости от длительности приёма препаратов витамина D были распределены на 4 группы: до 8 недель, 8-15 недель, 16-24 недели и более 24 недель.

Полученные результаты демонстрируют довольно низкую обеспеченность витамином D как на естественном, так и на искусственном вскармливании у детей грудного возраста. Установлено, что для поддержания оптимального уровня кальцидиола сыворотки (30 нг/мл и выше) у детей на первом году жизни оправдано применение более высоких профилактических доз витамина D (1000-1500 ME/сут), чем традиционно используемая доза 500 ME/сут, а оптимальная длительность курса должна составлять не менее 16 недель.

Ключевые слова: холекальциферол, недостаточность витамина $D$, дети, первый год жизни, профилактика, длительность приема, вскармливание

$\mathrm{T}$ he knowledge of vitamin $D$ has significantly evolved by now; the metabolic pathways of its activation in the human body have been clarified, and the location of specific receptors and related mechanisms of action of this hormone-like substance have been elucidated. There has been a radical change of opinion and conceptions of the prolonged «non-calcaemic» effects of vitamin D, which underlie various physiological functions and play the role of one of the universal regulators of homeostasis $[3,6$, $8,17]$. Vitamin $D$ deficiency, a common condition in the general population, is, on the contrary, closely related to an increased risk of both communicable and non-communicable diseases, which results in a $6 \%$ increase in overall mortality $[6,7,10,13,15]$.

As shown in numerous epidemiological studies, vitamin D insufficiency is found in almost half of the world's population $[4,5,19]$, including children, because the most active bone growth and mineralization processes occur during childhood and pubescence [6, 7, 14]. It has been shown; in particular, that $30 \%$ to $50 \%$ of the population residing in Europe and the United States have vitamin D insufficiency [17]. Recent population-based studies have demonstrated that the prevalence of hypovitaminosis $\mathrm{D}$ among children is also high. For instance, $61 \%$ of children residing in the United States have $25(\mathrm{OH}) \mathrm{D}$ concentrations in the range of $15-29 \mathrm{ng} / \mathrm{mL}$, and $9 \%$ of them have levels below $15 \mathrm{ng} / \mathrm{mL}$ [21].

Notwithstanding the growing relevance of this problem, the question of optimal dosing and, which is also important, optimal duration of cholecalciferol supplementation remains unanswered $[2,5,11,12$, $18,20,22]$. The choice which, unfortunately, has been dominant in this country to this day, is the so-called «seasonal» vitamin D supplementation method, which involves administration of cholecalciferol only during the autumn and winter period of the year; in the Southern regions, this period often lasts only 5 to 6 months, which is definitely an insufficient time to achieve and maintain an optimal calcifediol concentration [2, 5, 7, 9].

European investigators have established the following safe average daily allowances for vitamin D: 400-1000 IU/ day for newborns and infants and 600-1000 IU/day for children aged 1 year to 18 years. Vitamin D deficiency is partially compensated (i. e. the 25(OH)D concentration increases to $>30 \mathrm{ng} / \mathrm{mL}$ ) and no hypercalcaemia occurs in children and adolescents given such doses for 6 months. 25(OH)D concentrations of $30 \mathrm{ng} / \mathrm{mL}$ or higher are required for manifesta- tion of the extraskeletal effects of vitamin D. Additionally, the upper limit for serum calcifediol was established (30-50 ng/ $\mathrm{mL}$ or $75-125 \mathrm{nmol} / \mathrm{L}$ ) at which a switch to prophylactic cholecalciferol supplementation is recommended, because any levels of calcifediol above $50 \mathrm{ng} / \mathrm{mL}$ are considered by the authors to be a «high concentration necessitating a decrease of the therapeutic dose»[14, 18, 20, 22].

The Endocrine Society of the United States recommends using high doses of vitamin $D$ that allow to reach the $30 \mathrm{ng} / \mathrm{mL}$ level. For that purpose, the recommended daily dose is 400-1000 IU (not more than 2000 IU for safety reasons) for infants in the first year of life, 600-1000 IU (not more than $4000 \mathrm{IU}$ ) for children and adolescents from 1 year to 18 years of age, and 1500-2000 IU/day (not more than $10000 \mathrm{lU} /$ day) for adults over 18 years of age $[14,16,18]$.

Domestic experts have developed a so-called «scalelike» dosing regimen for vitamin $D$ supplementation in children of different age groups [9]. According to this regimen, the recommended daily allowances for vitamin $D$ are as follows: $500 \mathrm{IU} /$ day for infants under 4 months of age (800-1000 IU/day for prematurely born infants), $1000 \mathrm{lU} /$ day for infants and children aged from 4 months to 4 years; $1500 \mathrm{IU} /$ day for the age interval of 4 to 10 years, and 2000 IU/day for children from 10 to 16 years of age [2, 5, 9].

The objective of this study was to analyze the relationship between the duration of administration of different cholecalciferol doses and the 25(OH)D concentration in infants during their first year of life.

Material and Methods. The study sample consisted of 496 infants aged 1 to 12 months; 247 (49.8\%) of them were breastfed and 249 (50.2\%) were formula-fed.

Inclusion criteria: practically healthy infants aged 1 to 12 months without organic diseases and genetic syndromes, possibility of blood sampling, as well as Parental Informed Consent for recruitment in the study. Exclusion criteria: infants with a diagnosis of rickets, impaired hepatic (jaundice, diarrhea) or renal function, intrauterine growth restriction/hypotrophy grade $2-3$, malabsorption syndrome, as well as impaired mental development.

Regular vitamin D supplementation was administered to 191 breastfed infants ( $77.3 \%)$ : 138 of them $(72.3 \%)$ received a $500 \mathrm{IU} /$ day dose and 53 subjects $(27.7 \%)$ were given doses in the range of 1000-1500 IU/day. In the formula-fed arm, prevention of rickets and vitamin D insufficiency was used in 156 infants (62.7\%): 113 of them $(72.4 \%)$ received cholecalciferol preparations at a daily dose of $500 \mathrm{IU}$, and 43 infants (27.6 \%) were administered daily doses in the range of 1000 to $1500 \mathrm{IU}$. 
All subjects were divided into four groups depending on the duration of vitamin $D$ supplementation: up to 8 weeks $(n=85), 8-15$ weeks $(n=97), 16-24$ weeks $(n=59)$, and over 24 weeks $(n=106)$.

The 25(OH)D determination was performed by the immunofluorescence assay, using a Liaison DiaSorin Pleutschland $\mathrm{GmbH}$ analyzer (Germany).

Results pertaining to vitamin $D$ insufficiency were interpreted in accordance with the recommendations of the International Society of Endocrinology (2011): 25(OH)D concentrations below $10 \mathrm{ng} / \mathrm{mL}$ corresponded to severe vitamin $D$ deficiency; levels in the range of 10 to $20 \mathrm{ng} /$ $\mathrm{mL}$ were interpreted as a deficiency; $21-29 \mathrm{ng} / \mathrm{mL}$ as an insufficiency; and levels in the range of 30 to $100 \mathrm{mg} / \mathrm{mL}$ as a normal vitamin D content $[18,22]$.

Statistical analysis and evaluation of study results were performed using the Microsoft Excel, AtteStat, and Statistica 10.0 application packages. The Shapiro-Wilk test was applied for determination of the type of data distribution. For parametric quantitative variables, the arithmetic mean (M) and the standard error $(\mathrm{m})$ were calculated. For non-parametric qualitative variables, the median (Me) and the quartiles [25Q - 75Q] were estimated. Student's t-test was used for estimation of intergroup differences in case of normally distributed parametric data; the Mann - Whitney U-test and the Wilcoxon test were applied for non-parametric quantitative data showing non-normal distribution. The Pearson chi-squared test $\left(\chi^{2}\right)$ with adjustments for small-sized samples and the Fisher exact test (if one of the values was below 4 and the total number of values was less than 30 ) were applied for estimation of the statistical significance of differences between the quantitative data. The paired Pearson ( $r$ ) and Kendall correlation coefficients were used for evaluation of relationships between the parameters. Differences were considered statistically significant at $p \leq 0.05$ [1].

Results and Discussion. Subjects under the age of 12 months that were included in this study demonstrated rather low vitamin D levels: the median serum 25(OH)D concentration was found to be 28.5 [18.2-39.75] ng/mL. In the group of children who were administered cholecalciferol supplementation for prophylactic purposes, the serum calcifediol concentration was significantly higher than the respective value in the group that received no vitamin D supplementation: 32.5 [21.1-46.1] ng/mL and $21.9[12.9-30.3] \mathrm{ng} / \mathrm{mL}$, respectively $(p<0.001)$.

Our analysis of the effect of the duration of prophylactic supplementation demonstrated that vitamin D supplementation lasting less than 8 weeks could not ensure an optimal vitamin D content in study subjects (Table).

Table

Median serum 25(OH)D concentration in infants under the age of 12 months by duration of cholecalciferol supplementation

\begin{tabular}{|l|c|c|c|}
\hline $\begin{array}{c}\text { Duration } \\
\text { of cholecalci- } \\
\text { ferol } \\
\text { supplementa- } \\
\text { tion }\end{array}$ & $\begin{array}{c}\text { Mean vi- } \\
\text { tamin D } \\
\text { dose, IU/ } \\
\text { day }\end{array}$ & $\begin{array}{c}25(\mathrm{OH}) \mathrm{D} \text { con- } \\
\text { centration } \\
\text { Me (25Q - } \\
75 \mathrm{Q})\end{array}$ & $\mathrm{P}$ \\
\hline $\begin{array}{l}\text { up to } 8 \text { weeks } \\
(\mathrm{n}=85)\end{array}$ & $632.9 \pm 33.7$ & $\begin{array}{c}21.7 \\
(10.45-33.2)\end{array}$ & - \\
\hline $\begin{array}{l}8-15 \text { weeks } \\
(\mathrm{n}=97)\end{array}$ & $689.7 \pm 39.1$ & $\begin{array}{c}32.5 \\
(22.4-43.95)\end{array}$ & $\mathrm{p}=0.00122$ \\
\hline $\begin{array}{l}16-23 \text { weeks } \\
(\mathrm{n}=59)\end{array}$ & $754.2 \pm 51.8$ & $\begin{array}{c}35.6 \\
(22.5-48.7)\end{array}$ & $\mathrm{p}=0.000488$ \\
\hline $\begin{array}{l}24 \text { weeks or } \\
\text { longer (n=106) }\end{array}$ & $674.5 \pm 29.2$ & $\begin{array}{c}36.2 \\
(25.4-50.4)\end{array}$ & $\mathrm{p}=0.000011$ \\
\hline
\end{tabular}

The note: $\mathrm{p}$ - significance of the difference in the parameter with infants administered cholecalciferol supplementation for up to 8 weeks.
Analyzing the data included in Table, one can see that the average daily prophylactic dose of cholecalciferol did not change with statistical significance in the analyzed groups ( $p>0.05)$. At the same time, vitamin D supplementation courses lasting more than 8 weeks had a significant effect on the 25(OH)D concentration, as compared with shorter courses. Infants who received cholecalciferol supplementation for 8 to 15 weeks, had calcifediol levels that were 1.49 - fold $(p<0.005)$ higher, those given cholecalciferol for 16 to 23 weeks had 1.64 - fold $(p<0.001)$ higher levels, and those who received cholecalciferol for more than 24 weeks had 1.67 - fold $(p<0.001)$ higher levels compared with subjects given vitamin $D$ supplementation for not more than 2 months.

Analyzing the structure of vitamin $D$ insufficiency by duration of supplementation, we found that vitamin D supplementation given for 8-15 weeks resulted in a reduction in the number of patients with severe vitamin $D$ deficiency, from $23.5 \%$ to $9.2 \%(p<0.001)$. Besides, the same duration of supplementation resulted in a statistically significant increase in the number of infants with optimal vitamin D levels, as compared with shorter courses lasting up to 8 weeks, from $31.8 \%$ to $57.7 \%(p<0.001)$. A subsequent increase in the duration of cholecalciferol supplementation to 24 weeks or longer was associated with further increments in the 25(OH)D level and in the number of infants with normal vitamin $D$ content.

The Figure 1 presents obtained data on the structure of the effect of the duration of cholecalciferol supplementation at different prophylactic doses.

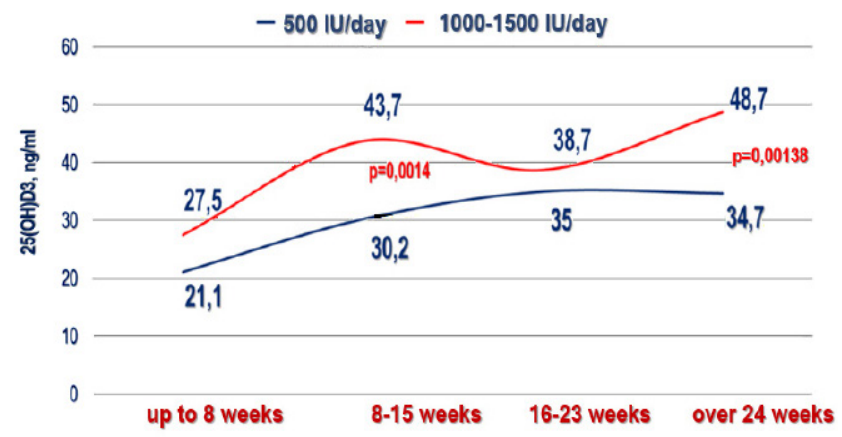

Fig. 1. Median calcifediol concentration in study subjects by the dose and duration of cholecalciferol supplementation

This analysis shows that the advantage of daily doses in the range of 1000-1500 IU/day over the $500 \mathrm{IU} /$ day dose is clearly manifested with any duration of the cholecalciferol supplementation course. It is also apparent, at the same time, that neither the $500 \mathrm{lU} /$ day dose nor the 1000-1500 IU/day doses can supply enough vitamin D to the infant's body if given for less than 8 weeks; however, the serum calcifediol concentration obtained with the 1000-1500 IU/day prophylactic doses even after such short course is significantly higher than that achieved with $500 \mathrm{lU} /$ day supplementation. With courses lasting longer than 8 weeks, the $25(\mathrm{OH}) \mathrm{D}$ concentration obtained with the $1000-1500$ IU/day doses is significantly higher than that achieved with the $500 \mathrm{IU} /$ day dose after supplementation for 8 to 15 weeks $(p<0.001)$ or more than 24 weeks $(p<0.001)$.

Analyzing how often serum 25(OH)D concentrations above $30 \mathrm{ng} / \mathrm{mL}$ could be achieved in infants administered the prophylactic doses (Fig. 2), we demonstrated that the target could be achieved only in $30 \%$ of subjects given the $500 \mathrm{IU} /$ day dose and in $37 \%$ of infants who received the 1000-1500 IU/day doses if supplementation lasted less than 8 weeks ( $p>0.05)$. 


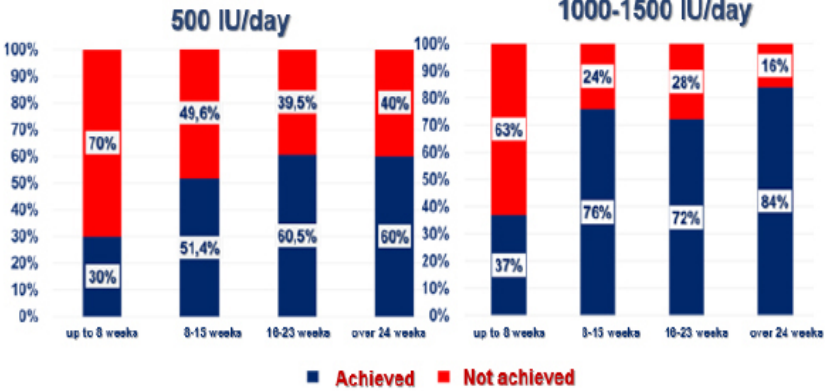

Fig. 2. Frequency of achieving optimal vitamin D saturation by the dose and duration of cholecalciferol supplementation

Afterwards, as the duration of cholecalciferol supplementation at 1000-1500 IU/day increased, the proportion of infants achieving normal vitamin $\mathrm{D}$ content significantly exceeded that found in infants given the $500 \mathrm{IU} /$ day ose $(p<0.001)$. Characteristically, even after 24 weeks of cholecalciferol supplementation at the $500 \mathrm{IU} /$ day dose, the proportion of infants achieving normal vitamin D content did not exceed $60 \%$, thus indicating insufficient efficacy of this prophylactic cholecalciferol dose that is conventionally used in this country.

Before the introduction of supplemental feeding, the principal source of cholecalciferol during the first year of life is breast milk or milk formulas. The content of cholecalciferol in modern adapted milk formulas is strictly regulated at the level of $400-500 \mathrm{IU}$ per litre of finished product $[5,7,14]$, whereas the content of vitamin $D$ in breast milk is significantly lower, lying in the range of 12 to $110 \mathrm{IU} / \mathrm{L}$ according to different sources [23, 24].

Formula-fed infants have significantly higher serum calcifediol concentrations compared with breastfed infants: 31.5 [22.2-39.3] ng/mL and 23.7 [10.9-38.8] ng/ $\mathrm{mL}$, respectively $(p=0.0006)$.

We analyzed the effects of prophylactic cholecalciferol supplementation on the vitamin D content by the type of feeding. The Figure 3 shows the changes in median serum calcifediol concentration observed in breastfed infants.

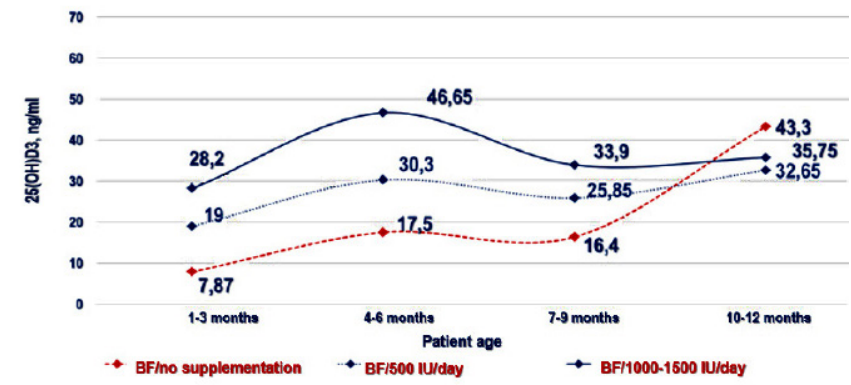

Fig. 3. Changes in 25(OH)D concentration in breastfed infants during their first year of life

Figure 3 demonstrates that breastfed infants given no cholecalciferol supplementation had extremely low vitamin $\mathrm{D}$ content practically throughout the first year of life: 7.87 [4.5-14.4] $\mathrm{ng} / \mathrm{mL}$ in the first quarter, 17.5 [13.022.2] $\mathrm{ng} / \mathrm{mL}$ in the second, and 16.4 [9.0-21.2] $\mathrm{ng} / \mathrm{mL}$ in the third quarter, respectively, which is considered to be indicative of vitamin D deficiency. The $25(\mathrm{OH}) \mathrm{D}$ increment to $43.3 \mathrm{ng} / \mathrm{mL}$ in the fourth quarter was probably due to the diet becoming significantly richer as a result of the introduction of cholecalciferol-fortified supplemental feeding.

In breastfed infants, daily vitamin D supplementation with the prophylactic $500 \mathrm{IU} /$ day dose was associated with an increase in serum 25(OH)D: 19.0 [8.39-32.7] ng/
$\mathrm{mL}$ in the first quarter $(\mathrm{p}<0.05), 30.3[18.3-38.8] \mathrm{ng} / \mathrm{mL}$ in the second $(p<0.05), 25.85[22.8-34.7] \mathrm{ng} / \mathrm{mL}$ in the third $(p<0.01)$, and 32.65 [16.6-43.4] ng/mL in the fourth quarter $(p>0.05)$ of the first year of life. Apparently, the use of the $500 \mathrm{IU} /$ day dose in breastfed infants is far from fully consistent with the current strategy of achieving optimal vitamin $D$ content throughout life, because a stable level of $30 \mathrm{ng} / \mathrm{mL}$ is only achieved by the fourth quarter of life if this dose is given.

Vitamin D supplementation with doses in the range of 1000-1500 IU/day results in a higher calcifediol increment in infants in the first, second, and third quarters, compared not only with infants receiving no vitamin $D$ supplementation but also with those given the $500 \mathrm{IU} /$ day dose. It is evident that the extremely low content of cholecalciferol in breast milk warrants a recommendation to start vitamin D supplementation in breastfed infants as soon as possible and give it all year round; the recommended dose of cholecalciferol for breastfed infants is at least $1,000 \mathrm{IU} /$ day.

Our analysis conducted in the group of infants given adapted milk formulas demonstrated similar changes (Fig. 4).

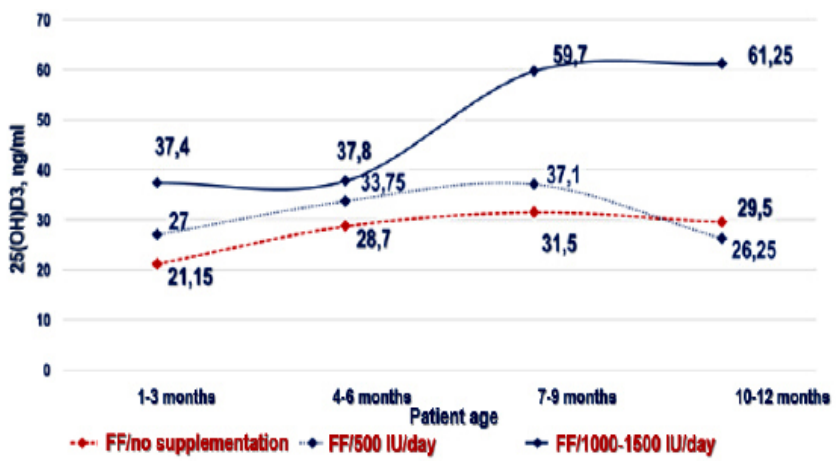

Fig. 4. Changes in 25(OH)D concentration in formula-fed infants during their first year of life

Formula-fed infants who receive no vitamin $D$ supplementation also have $25(\mathrm{OH}) \mathrm{D}$ concentrations that are lower throughout infancy than those in infants receiving cholecalciferol supplementation. Although their median $25(\mathrm{OH}) \mathrm{D}$ concentration is higher than that in breastfed infants, it still lies in the range of $20-30 \mathrm{ng} / \mathrm{mL}$ characteristic of vitamin $D$ insufficiency. It is essential to underline that formula feeding without additional use of cholecalciferol supplements allows to achieve normal saturation with vitamin D in only $23 \%$ of infants in their first year of life. Notwithstanding the fact that fortification of currently available adapted formulas with cholecalciferol significantly decreases the risk of severe vitamin D deficiency, it is still obviously insufficient to achieve a normal vitamin D status and does not allow to completely satisfy an infant's requirements during the first year of life in the absence of pharmacological supplementation.

Cholecalciferol supplementation at $500 \mathrm{IU} /$ day was associated with an increasein serum 25(OH)D: 27.0 [19.6$37.45] \mathrm{ng} / \mathrm{mL}$ in the first quarter $(p<0.05), 33.75$ [28.5$46.1] \mathrm{ng} / \mathrm{mL}$ in the second $(p<0.01), 37.1$ [31.8-43.6] ng/ $\mathrm{mL}$ in the third quarter $(\mathrm{p}<0.05)$, and with a certain decrease, to 26.25 [18.0-35.8] ng/mL, in the fourth quarter $(p>0.05)$. Daily cholecalciferol supplementation at 1000$1500 \mathrm{IU} /$ day is characterized by an even higher increase in $25(\mathrm{OH}) \mathrm{D}$, with the concentrations in the third and fourth quarters being $59.7[48.2-71.8] \mathrm{ng} / \mathrm{mL}(p<0.001)$ and 61.25 [34.9-88.5] ng/mL $(p<0.05)$, respectively.

Characteristically, the rather apparent dose-dependent effect is potentiated by progressive duration of chole- 
calciferol supplementation over a few months, and this combination ensures a normal $25(\mathrm{OH}) \mathrm{D}$ level in the majority of infants. Correlation analysis demonstrated a direct relationship between the duration of cholecalciferol supplementation and the 25(OH)D level $(r=0.3, p=0.00004)$.

Conclusions. The results obtained in this study demonstrate rather low vitamin D levels in infants. Supplementation of $500 \mathrm{IU} /$ day as a prophylactic dose given for less than 8 weeksdoes not allow to achieve an optimal 25(OH)D level. Use of higher prophylactic doses of vitamin D (1000$1500 \mathrm{lU} /$ day) is justified if the aim is to maintain an optimal serum calcifediol concentration in infants in their first year of life, and supplementation should last longer than 8 weeks.

\section{References}

1. Glants S. Mediko-biologicheskaya statistika. Praktika. 1998, 459 .

2. Gromova O. A., Torshin I. Yu., Zakharova I. N., Spirichev V. B., Limanova O. A. [et al.]. O dozirovanii vitamina D u detey I podrostkov. Voprosy sovremennoy pediatrii. 2015;14(1):38-47. doi: 10.15690/vsp.v14i1.1261

3. Gromova O. A., Torshin I. Yu.; pod red. akad. RAN Ye. I. Guseva, prof. I. N. Zakharovoy. Vitamin D - smena paradigm. 2017, 576 .

4. Zakharova I. N., Klimov L. Ya., Kuryaninova V. A., Dolbnya S. V., Maykova I. D. [et al.]. Obespechennost vitaminom D detey grudnogo vozrasta. Rossysky vestnik perinatologii $i$ pediatrii. 2016;61(6):68-76. doi: 10.21508/1027-4065-2016-61-6-68-76

5. Zakharova I. N., Klimov L. Ya., Maltsev S. V., Malyavskaya S. I., Gromova O. A. [etal.]. Korrektsiyanedostatochnosti vitamina $D$ u detey rannego vozrasta $v$ Rossyskoy Federatsii (rezultaty issledovaniya RODNIChOK-2). Pediatriya. Prilozheniye k zhurnalu Consilium Medicum. 2017:1:73-81.

6. Zakharova I. N., Yablochkova S. V., Dmitriyeva Yu. A. Izvestnye I neizvestnye effekty vitamina D. Voprosy sovremennoy pediatrii. 2013;12(2):20-26. doi: 10.15690/vsp.v12i2.616

7. Zakharova I. N., Klimov L. Ya., Kuryaninova V. A. Gromova O. A.,' Dolbnya S. V.' [et al.] Effektivnost profilaktiki gipovitaminoza D u detey pervogo goda zhizni: rol vskarmlivaniya, vliyaniye dozy I dlitelnosti primeneniya preparatov kholekaltsiferola. Pediatriya. Zhurnal im. G. N. Speranskogo. 2016;95(6):62-69. doi: 10.24110/0031-403X-2016-95-6-62-70

8. Maltsev S. V., Mansurova G. Sh. Metaboliz mvitamina D I puti realizatsii ego osnovnykh funktsy. Prakticheskaya meditsina. 2014:9(85):12-18.

9. Natsionalnaya programma «Nedostatochnost vitamina D u detey I podrostkov $v$ Rossyskoy Federatsii: sovremennye podkhody k korrektsii». 2017, 50.

10. Rudyk A. V. Rol vitamina D v protivoinfektsionnom immunitete. Epidemiologiya i infektsionnye bolezni. Aktualnye voprosy. 2017; 1: 54-57.

11. Ahlawat R., Weinstein T., Pettei M.J. Vitamin D in pediatric gastrointestinal disease. Curr. Opin. Pediatr. 2017;29 (1):122-127. doi: 10.1097/MOP.0000000000000451

12. Alonso A., Rodríguez J., Carvajal I., Prieto M. L., Rodríguez R. M. [et al.] Prophylactic vitamin $D$ in healthy infants: assessing the need. Metabolism. 2011;60(12): 1719-1725. doi: 10.1016/j.metabol.2011.04.011

13. Auter Ph., Gandini S.Vitamin D supplementation and total mortality. Arch. Intern. Med. 2007;167(16):17301737. doi: $10.1001 /$ archinte.167.16.1730
We analyzed the effects of prophylactic cholecalciferol supplementation on the vitamin $D$ content by the type of feeding. Low content of cholecalciferol in breast milk warrants a recommendation to start vitamin D supplementation in breastfed infants as soon as possible and give it all year round; the recommended dose of cholecalciferol for breastfed infants is at least $1000 \mathrm{IU} /$ day. Infants given adapted formulas fortified with cholecalciferol are at a lower risk of developing severe vitamin D deficiency, but this feeding is still obviously insufficient to achieve a normal vitamin D status and does not allow to completely satisfy an infant's requirements during the first year of life in the absence of pharmacological supplementation.

14. Munns C. F., Shaw N., Kiely M., Specker B. L., Thacher T. D. [et al.] Global consensus recommendations on prevention and management of nutritional rickets. J. Clin. Endocrinol. Metab. 2016;101(2):394-415. doi: 10.1210/jc.2015-2175

15. Grant W. B. The role of vitamin D supplements in treating health condition and diseases common among those with intellectual and/or developmental disabilities. Standardy Medyczne pediatria. 2015;12(5):775-780.

16. Hanson C., Armas L., Lyden E., Anderson-Berry A. Vitamin D status and associations in newborn formula-fed infants during initial hospitalization. J. Am. Diet Assoc. 2011;111(12):1836-1843. doi: 10.1016/j. jada.2011.09.010

17. HolickM. F. VitaminDstatus: measurement, interpretation, and clinical application. Ann. Epidemiol 2009;19(2):7378. doi: 10.1016/j.annepidem.2007.12.001

18. Holick M. F., Binkley N. C., Bischoff-Ferrari H. A., Gordon C. M., Hanley D. A. [et al.].Evaluation, treatment, and prevention of vitamin D deficiency: an Endocrine Society clinical practice guideline. J. Clin. Endocrinol. Metab. 2011;96:1911-1930. doi: 10.1210/jc.2011-0385

19. Holick M. F. Vitamin D deficiency. N. Engl. J. Med. 2007;357:266-281. doi:10.1056/NEJMra070553

20. Klimov L. Ya., Kuryaninova V. A., Zakharova I. N., Dolbnya S. V., Kasyanova A. N. [et al.] Influence of duration of cholecalciferol products administration on the efficacy of hypovitaminosis $D$ prevention in children during the first year of life. Eur. J. Pediatrics. 2016;175(5):343.

21. Kumar J., Muntner P. Kaskel F J. Hailpern S. M MLM Prevalence and associations of 25-hydroxyvitamind D deficiency in US children: NHANES 2001-2004. Pediatrics. 2009;124:362-370. doi: 10.1542/ peds.2009-0051

22. Pludowski P., Holick F., Grant W. B., Konstantynowicz J., Mascarenhas M. R. [et al.].Vitamin D supplementation guidelines. J. Steroid Biochem. Mol. Biol. 2017; 12: pii: S0960-0760(17)30031-6. doi: 10.1016/j.jsbmb.2017.01.021

23. Streym S., Højskov C. S., Møller U. K., Heickendorff L., Vestergaard P. [et al.] Vitamin 'D content in human breast milk: a 9-mo follow-up study. Am. J. Clin. Nutr. 2016;103(1):107-114. doi: 10.3945/ ajcn.115.115105

24. Wall C. R., Stewart A. W., Camargo C. A., Scragg R. Mitchell E. A. [et al.] Vitamin D activity of breast milk in women randomly assigned to vitamin D3 supplementation during pregnancy. Am. J. Clin. Nutr. 2016;103(2):382-388. doi: 10.3945/ajen.115.114603

\section{About authors:}

Klimov Leonid Yakovlevich, CMSc, Associate Professor, Head of the Department of Faculty Paediatrics; e-mail: klimov_leo@mail.ru Zakharova Irina Nikolaevna, DMSc, Professor, Honorary Physician of the Russian Federation, Chief Paediatrician of the Central Federal Okrug, Head of the Department of Paediatrics; tel.: +74992522104; e-mail: zakharova-rmapo@yandex.ru

Maltsev Stanislav Viktorovich, DMSc, Professor, Honorary Worker of Science of the Russian Federation, Professor of the Department of Paediatrics; e-mail: maltc@mail.ru

Malyavskaya Svetlana Ivanovna, DMSc, Professor, Vice-Principal for Research, Head of the Department of Faculty Paediatrics; e-mail: malyavskay@yandex.ru

Yagupova Anastasiya Valeryevna, Assistant Teacher of the Department of Faculty Paediatrics; e-mail: yagupova.anastasya@yandex.com Dolbnya Svetlana Viktorovna, CMSc, Assistant Teacher of the Department of Faculty Paediatrics; e-mail: svet-lana.dolbnya@yandex.ru Kasyanova Anna Nikolaevna, Clinical Resident of the Department of Paediatrics; e-mail: a.nicolaevnakasjanova@yandex.ru Kuryaninova Viktoriya Aleksandrovna, CMSc, Assistant Teacher of the Department of Paediatric Propaedeutics; e-mail: vichkak@mail.ru 